Portland State University

PDXScholar

Dissertations and Theses

Dissertations and Theses

1975

\title{
Structure vs. Meaning in Subliminal Perception
}

Margaret Anne Callan Hoisington

Portland State University

Follow this and additional works at: https://pdxscholar.library.pdx.edu/open_access_etds

Part of the Cognition and Perception Commons

Let us know how access to this document benefits you.

Recommended Citation

Hoisington, Margaret Anne Callan, "Structure vs. Meaning in Subliminal Perception" (1975). Dissertations and Theses. Paper 2149.

https://doi.org/10.15760/etd.2147

This Thesis is brought to you for free and open access. It has been accepted for inclusion in Dissertations and Theses by an authorized administrator of PDXScholar. Please contact us if we can make this document more accessible: pdxscholar@pdx.edu. 
AN ABSTRACT OF THE THESIS OF Margaret Callan Hoisington for the Master of Science in Psychology presented November 26, 1975.

Title: Structure vs. Meaning in Subliminal Perception

APPROVED BY MEMBERS OF THE THESIS COMMITTEE:
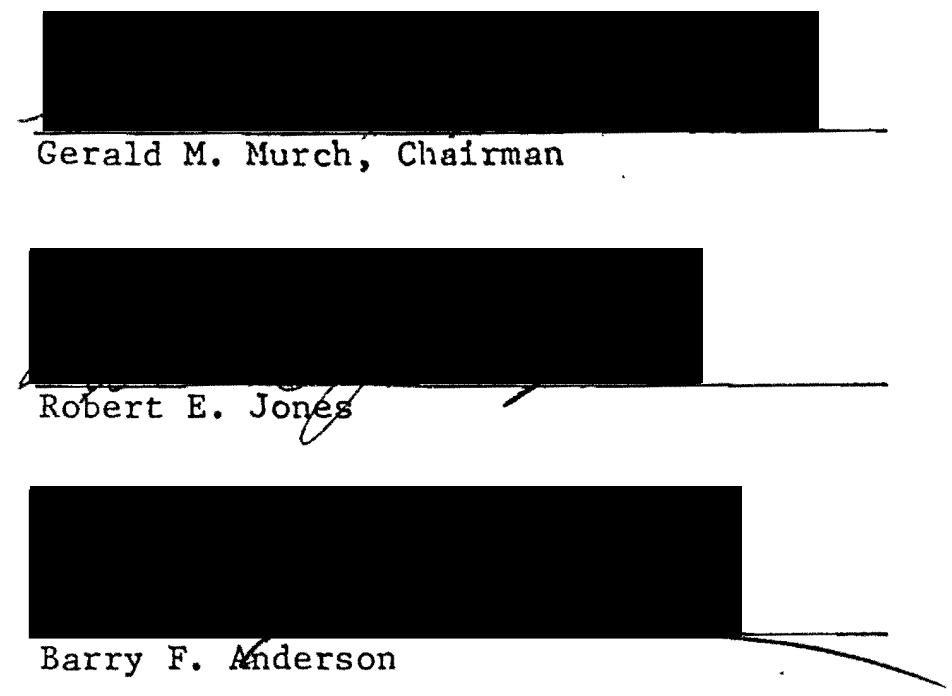

Subliminal perception is defined as a process whereby a subject reports no awareness of a visual stimulus, and yet his/her verbal behavior, subjectively experienced as "guesses", is influenced by the stimulation. Various studies have found evidence for and against subliminal perception using discrimination tasks and subjective judgments. Explanations of subliminal perception include the partial cue hypothesis, the theory of perception of structural differences, and the theory that responses to subliminal stimuli are of $a^{*}$ semantic nature. This study was conducted to determine whether subliminal perception involves a discrimination of structural characteristics or a discrimination of the semantic quality of words prior to specific identification. It was also an attempt to find the relationship between the level of stimulus awareness and the type of response. During the 
first part of the experiment individual thresholds were measured for thirty-two Ss on a three channel tachistoscope, using an increasing method of limits. Subliminal, partial cue, and supraliminal exposure durations were determined for each $\underline{S}$.

During the second part of the experiment, the stimulus word was flashed at one of the three exposure durations and followed $150 \mathrm{msec}$. later by two words. The $\underline{S}$ was asked to report what he/she saw before the two choice words appeared and then to choose one of the words.

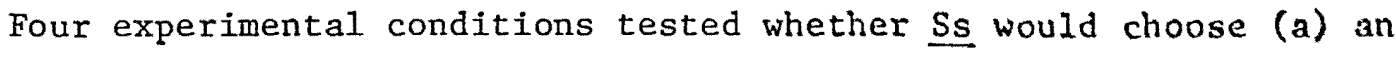
identical word significantly more often than a neutral word (that is, one neither structurally similar nor an associate) (Condition S+M); (b) a structurally similar word more frequently than a neutral word (Condition S); (c) an associate more frequently than a neutral word (Condition $\mathrm{M}$ ); or (d) a structurally similar word more frequently than an associate (Condition $S-M$ ).

Experiment II differed from Experiment I in that the method of threshold measurement was changed to match that in the main part of the study. The stimulus was followed $150 \mathrm{msec}$. later by the cholce words instead of being presented alone. Ss were asked to report what they saw before the choice words were seen.

Results from Experiment I showed that the Ss didn't seo anything in a significant number of the trials when they should have, according to previous threshold measurements. The data from Experiment II showed that there was a better correlation, although not a perfoct onc, between what the Ss should have seen, according to the threshold mcasurement, and what-they reported during the second part of the cxperiment... The normal curve test was performed on the data from lixperiment if 
for all Ss combined to find whether there was a signiflcant difference in choice behavior when the Ss reported nothing, a partial cue, or a word during each of the subliminal, partial cue, and supraliminal exposure durations. It was found that seven of the significant differences in choice behavior occurred when the $S$ could Identify the word during the study. The Ss chose an identical word significantly more often than a neutral word when they reported no awarencss of the stimulus, but at an exposure duration previously established as above threshold. The results were explained in terms of signal detection thcory. 
STRUCTURE VS. MEANING IN SUBLIMINAL PERCEPTION

\section{by}

Margaret Anne Callan Hoisiugton

A thesis submitted in partial fulfillment of the requirements for the degree of

\section{MASTER OF SCIENCE}

in

PSYCHOLOGY

Portland State University

1975 
TO THE OFFICE OF GRADUATE STUDIES:

The members of the Committee approve the thesis of Margaret Callan Hoisington presented November 26, 1975.

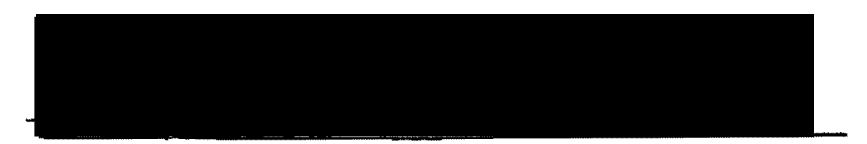

Gerald M. Murch, Chairman
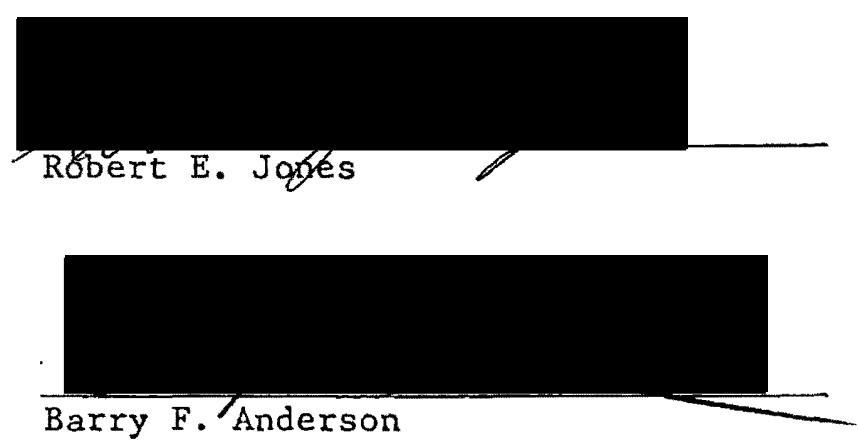

APPROVED :
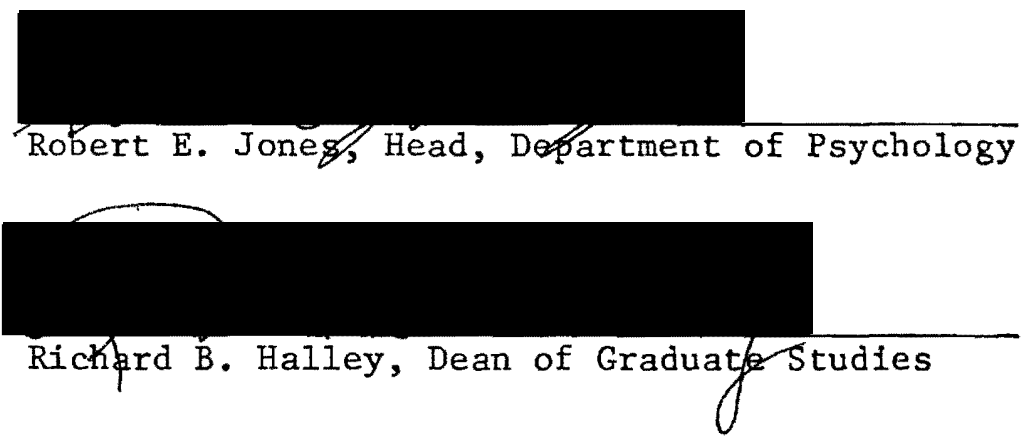

November 26, 1975 
TABLE OF CONTENTS

PAGE

LIST OF TABLES . . . . . . . . . . . . . . • •

CHAPTER

I INTRODUCTION AND REVIEW OF LITERATURE . . . . .

Studies Supporting Subliminal Effects . . . 2

Partial Cue Hypothesis... . . . . . 6

Alternative Explanations . . . . . . . s

Opposing Views of Subliminal Perception . . . 12

Structural Subliminal Effects . . . . 13

Subliminal Effects of a Semantic Nature . 15

Relationship Between Stimulus Intensity and

Type of Response... . . . . . . 20

II RESEARCH PROJECT . . . . . . . . . . . 22

Method ............... 23

Apparatus . . . . . . . . . . 23

Procedure ............ . . 25

Experiment I ......... 25

Experiment II......... 26

Subjects ............. . . . 26

Statistical Analysis . . . . . . . 27

Results .............. . . . 27

II DISCUSSION . . . . . . . . . . . 30

Conclusion .................. 34

BIBLIOGRAPHY . . . . . . . . . . . . . . . 36 


\section{LIST OF TABLES}

TABLE

PAGE

I Stimulus Duration as Defined in Threshold Mcasurement and in the Experiment............ 41

II Significant Differences in Choice Behavior . . . . . 42

III Stimulus Words and Choice Words . . . . . . . . 43 
CHAPTER I

\section{INTRODUCTION AND REVIEW OF LITERATURE}

The phenomenon of subliminal perception has aroused much controversy, not only in terms of its nature, but in terms of its very existence. The idea was first formulated, as far as we know, by philosophers who wrote around $400 \mathrm{~B} . \mathrm{C}$. It was not until the middle of the nineteenth century, however, that experimental work in the area was begun (Dixon, 1971).

A major problem with research on subliminal perception has been the lack of an operational definition for subliminal perception. In the context of this study, which deals with subliminal visual perception, it is defined as a process whereby a subfect reports no awarencss of a visual stimulus and yet his/her verbal bchavior, subjectively experienced as "guesses" is influenced by the stimulation. The threshold is the value, defined in terms of exposure duration and/or illumination, below which a response does not occur and above which it does. Above threshold values are called supraliminal.

In accordance with Murch's (1964) suggestion for tcrminology, this study will be classified as subliminal perception, rather than subception, because a supraliminal stimulus will be used in connection with a subliminal stimulus. The term subception is uscd in experiments which deal only with discrimination without awarencss. 


\section{STUDIES SUPPORTING SUBLIMINAL PERCEPTION}

Much of the early work which provided evidence for subliminal perception was done with the Muller-Lyer and other 11lusions. Dunlap (1900) found subjects to be susceptible to the Muller-Lyer illusion when the arrows were presented at subliminal light intensity. This illusion is one that makes a line with two arrows cxtending outward at the ends appear longer than a line of equal length with two arrows extending inward at the ends. Dunlap exposed subjects to a white screen with a black line drawn across it horizontally and divided in the center by a perpendicular line three-quarters of a milimeter in width and extending eight millimeters on each sidc. The arrotis werc placed behind the screen and illuminated from that sidc so that they were visible with high intensities of illumination. However, during the study illumination intensities were used at which the subjects could not distinguish one geometrical shape from another. Three arrows were used, one at each end of the black line and one in the middle so that the left half of the line appeared to be longer or shorter than the right half. The subject's judgment as to the length of the left half of the line compared with the right segment was recorded. It was found that a significant number of the subjects' judgments were in accordance with the Muller-Lyer illusion, although they reported no awareness of the inducing arrows.

Bressler (1931) found similar results in a repctition of Dunlap's study. However, the illusion created by the Imperceptible arrows was smaller than that created by clearly visible arrows in proportion to the intensity of the stimulus. Kennett(1962) also studled the offects 
of the Muller-Lyer illusion with the stimulus presented at mean threshold, one standard deviation below mean threshold, and two standard deviations above. Thresholds were determined separately for each subject. It was found that the subjects' judgments of line length were affected, to a significant degree, by the illusion at all three light intensity levels, but the effect was a reversal of the usual illusion. The greatest effect was at subthreshold light intensity.

Smith and Henrikson (1955) found evidence for the Zoellner illusion when the fan was presented at subliminal cxposure durations. When a fan-shaped array of lines was shown sublininally and followed by a clearly perceptible square, the square became trapczoidal, a change consistent with the usual illusion that appears when a square is seen against a fan-shaped background. Sinilar results were found by Farné (1963) where an illusory change in the slze of test figures was found at stimulus levels at which subjects reported no awareness of the inducing lines. Goldstein (1960) found a difference in the ratings of test figures when an illusory pattern was presented at subliminal light intensities. Subjectlve judghents were influenced by a stimulus of subliminal exposure duration in a study by Boardman and Goldstone (1962). The sizes of subliminal anchor disci produced shifts in judgment of a clearly perceptible disc.

Several studies have found that correct discriminations were made with greater than chance probability when the stimuli were below the subject's threshold. Sidis was one of the first fuvestigators to do studies of this type. He cites several of his own studies (S1dis, 1898) where guesses regarding the nature of letcors, rigures, and proper names, presented at too great a distance for consclous diacrim- 
ination, were correct more often than could be ascribed to chance. Stroh, Shaw, and Washburn (1908) found that subjects could discriminate between ten letters of the alphabet when the letters wore at such a distance that they were only visible as a faint spot on a card. Similar results were found in a study by Baker (1937) where subjects had to discriminate between subliminal perpendicularly crossed lines in the "plus" and "multiplication" positions. Light intensity was increased and decreased to find the visual threshold for each subject and discriminations were made from six units above and below the threshold. The subjects made correct discriminations at greater than chance probability, however a greater number of correct discriminations were made at higher stimulus levels. The same relationship between percent of correct discriminations and stimulus intensity was found by Miller (1939) in which subjects could discriminate between subliminal geometric figures. Williams (1938) also found that subjects could diseriminate betwecn subliminal geometric figures, however there was no rolationship bctwcen the number of correct guesses and the intensity of the stimulation. In a similar study, Schiff (1961) found that accuracy of guessing geometric figures for the experimental group exceeded that of a control group where the experimental group was exposed to the flgures at a speed and illumination below the lowest measured throshold and the control group was exposed to blank slides.

Subjects chose a subliminal geometric figure significantly morc often than one not shown at subliminal durations in $\mathbf{n}$ study by Murch (1965). Another study (Murch, 1967) reported additional cuidence lo: subliminal perception and showed a relationship betwen the time between presentation of the subliminal stimulus and prosentation of the 
response categories. The subjects selected those letter palrs for which they had received subliminal cues. However, the subliminal effects were "extinguished or inhibited in some manner unless the response categories, allowing the stimulus elements to be applied, are presented within a period of .25 sec." (Murch, 1967).

Related studies have been done where subjects were required to make judgments of a supraliminal stimulus which had been altered in some way by a subliminal stimulus. Subliminal effects were found by Worthington (1964) in a study where subjects were asked to reproduce Bartlett's (1932) "Mulak" figure which was shown on either a square or circular background of subliminal light intensity. The angularity or curviness of the subjectis reproduction was related to the background stimulus which was used.

Another type of study was done by Lazarus and Mccleary (1951) in which shock conditioned nonsense syllables vere found to cvoke significant GSRs even when presented too brlefly for verbal recognition. Ten nonsense syllables were presented tachistoscopically and the GSR was conditioned to the five experimental syllables using electric shock as the unconditioned stimulus, until consistent conditioned responses were established to them. During the final test period flve exposure speeds were used, ranging from one hundred percont recognition at the slowest speed to an accuracy of recognition which did not differ significantly from chance, at the fastest exposure speed. It was found that the GSR was significantly greater when the subject was not able to perceive the syllable correctly than when he/she could jdenciry the syllable. This study is noteworthy in that it concludes that subliminal stimuli influence autonomic responses as well as verbal 
behavior.

II. PARTIAL CUE HYPOTHESIS

Many studies have found no evidence for subliminal perception and report that what appears to be perception without awareness is, in fact, werely the elaboration of information received from fragments of the stimulus.

In a study by Bricker and Chapanis (1953) subjects were required to guess the nature of a stimulus presented at subliminal duration and intensity from a given list of possibilities. Some of the stimuli presented were on the list and some weren't. The stimuli were presented at an exposure duration and illumination where the subject consistently got half or less of the stimuli correct. Even when the subject was unable to report the correct stimulus, he/she was right more often than could be expected by chance if he/she was forced to gucss. Ihis finding is taken to imply that the subject was aware of part of the stimulus and it was this part which governed his/her selection. Nelsser (1967) disagrees with the concept of unconscious processing and states, in reference to the above study, "the fragment which the subfect secs on a given trial may be enough to trigger a correct roport".

Murdock (1953) ran a similar study in which ton nonsense syllables were presented at near-threshold 11 lumination levels. Aftcr cach presentation the subject ranked all ten syllables in order of decreasing probability of being the one stimulus actually prosented. When the first response was wrong, the correct responses were st11d above chance at upper-middle levels of illumination, thus suggesting that partial recognition does occur. 
Results of a study by Voor (1956) differed from a sim1lar study by Lazarus and McCleary (1951) and showed additional evidence for the partial cue hypothesis. Shock-associated and nonshock-associated nonsense syllables were presented at high (subjects could Identify 50\% of the presentations), medium (correct identification of $25 \%-33 \%$ ), and 1 ow (chance expectancy) illumination levels. Subfects were required to guess the nonsense syllable from a list given to him/her and his/her GSR was recorded with the presentation of each syllable. The GSR was significant at high illumination settings but barely signiflcant at low settings. Contrary to the findings of Lazarus and McCleary (1951), Voor concluded that there is no evidence of autonomic discrimination without awareness; rather the GSR seems to be mediated by the partial recognition that the subject gets from the presentation.

Boardman (1957) found that gross discriminations were accomplished well below the temporal recognition threshold, while finer discriminations were often made coincident with recognition.

In a study by Goldberg and Fiss (1959) subjects were exposed to a stimulus at exposure durations where partial recognition was possible at least some of the time and exposure durations where partial recognition never occurred. It was found that when partial cues weren't available, correct guesses were found to be no more frequent than was expected by chance. These investigators conclude that:

the results support the concept of continuous reception of information rather than the concept of a "scusory threshold" above which response occurs and below which it docs not. (Goldberg and Fiss, 1959)

Wiener and Schiller (1960) found a relationilitp between the degree of awareness of a visual stimulus and the emflting of a structur- 
ally similar response. There was no effect upon cholce behavior when the subjects reported not seeing the stimulus at all. Thelr findings were also similar to those of Voor(1956), in that they found autonomic discrimination without awareness to be a generaldzation response to the perception of some part of the original conditioned stimulus.

Some of the other work giving support of the partial cue hypothesis includes that of Kempler and Wiener $(1963,1964)$ and Wiencr and Klecspies (1968).

Guthrie and Wiener (1966) replicated a study by Eagle (1959) with some variations in the stimuli. They presented plctorial stimuli to subjects at subliminal exposure durations and the subfects made judgments of the stimuli from an adjective checklist. With variations in the thematic content and structural characteristics of the stimuli it was found that the subjects' judgments were related to the structural aspects of the stimuli. They conclude that:

The part-cue response-characteristic explanation can account for the so-called subliminal effects without having to invoke a special process which responds to differcnt classes of stimuli without the awareness of the subjects. (Guthrie and Wiener, 1966)

\section{ALTERNATIVE EXPLANATIONS}

In addition to the partial cue hypothesis, which offers an alternative explanation for the results of subliminal perception studies, some investigators have found no evidence for subliminal perception and offer other alternative explanations.

Three studies were run similar to that of Dunlap (1900) on the Muller-Lyer illusion with results in opposition to hio. Titchner and Pyle (1907), Washburn and Manro (1908), and Trimble and Erikgen (1906) 
found no evidence for the Muller-Lyer illusion when the arrows were presented at subliminal luminance intensity.

Eriksen (1958, 1960), in partial reviews of the I1terature, concludes that there is no convincing evidence that the human organism can discriminate or differentially respond to extcrnal stimull at a level that is more sensitive than what can be obtalned by verbal report. He also disagrees with the notion that gross affective discriminations can be made at levels below awareness.

In reference to the results obtained by Lasarus and McCleary(1951), Eriksen (1956 a \& b) postulates a partial correlation cxplanation rather than explanations of discrimination without verbal awareness. With partial correlation:

the only requirement (for this effect) is that two separate responses be made to the stimulus and that these responses be less than perfectly correlated with each other. Viewed from the standpoint of partial correlation the subception effect is not surprising, but is actually the expected outcome. (Eriksen, 1956 b)

An experiment on stimulus-generalization was performed to test the adequacy of this formulation. Two groups of subjects were conditioned to give concurrently a GSR and a verbal response to a square of a given size. During the generalization trials one group of subjects was allowed to use eleven different verbal responses and the other group was permitted only two verbal responses. The subjects with only two verbal response categories were found to give signiflcantly more generalized verbal responses, but there was no evidence of any difference in GSR generalization between the two groups. The data from both groups showed evidence of subliminal perception. When verbal responses were held constant, the magnitude of GSR varied systomatically with the $5 i=0$ 
of the stimulus. These results not only substantiated the partial correlation explanation; they also supported Eriksen's criticlsm of the Lazarus and McCleary (1951) study in terms of the limited number of response categories available. The data for the eleven response group In the above study shows that subjects were capable of "conscious" discrimination when they were allowed the necessary verbal categories.

Champion and Turner (1959) exposed subjects to a thirty minute film during which a spoon of rice with the words "Wonder Rice" was shown at subliminal exposure duration to the experinental group and a control stimulus was shown to the other group. Subjects later indicated if they recognized the advertisement and-were asked to choose one of two brands they believed to be most likely associated with the illustration. The two groups did not differ significantly in their cholces and the investigators conclude that the subliminal presentation had no effect on the responses of the subjects.

Calvin and Dollenmayer (1959) ran a pseudo-ESP study in which subjects were required to guess which of two circles (left or right) was correct on a certain,trial. The words CHOOSE LEFT or CHOOSE RIGHT were flashed at exposure speeds at and below threshold. Nelther of the . groups were correct significantly greater than chance expectancy. The four subjects who made a significant number of correct cliolces indicated that they had been able to see the words.

A recent study by Kleespies and Wiener (1972) looked at frequency and latency of first eye movements (orienting reflex) at subliminal exposure durations and whether the response, if any, was a function of the thematic content of the stimulus. Exposurc durations at subliminal, part-cue, and supraliminal levels were determined by a group of pllot 
subjects. The stimulus was varied from threatening to non-threatening in both structure and thematic content. In addition to the recording of first eye movements, the subjects were told to press a button if they thought they saw something. Results failed to show any evidonce of a difference in first eye movements which are a function of either thematic content or structure at any exposure duration. There was less evidence of input experience at a subliminal exposure duration as compared with part-cue or identification. The investigators conclude that:

there is still some question as to whether therc is any visual input at all under the kinds of subliminal exposure conditions typically employed, much less a discrimination of threatening vs. non-threatening stimulus content (Kleespies and Wiener, 1972).

Researchers have investigated the effect of subliminal slimuli on recall of words. Gardner and Lorenz (1962) gave subjects a list of twenty-six words, ten of which were associates to the word CHIESE and ten control words which were non-associates. The words were read to the subjects while the experimental group was exposed to the word CllEESE flashed at subliminal exposure duration. Both groups recalled more CHEESE associates than control words, independent of the subliminal stimulus. The conclusion drawn from this is that the superior recall of CHEESE associates was apparently due to their common associative link, rather than to a subliminal effect. In a simllar study, Bernstein and Eriksen (1965) found that a correct cue facllicates learning only if presented at a level sufficient to allow betire than chance forcedchoice recognition accuracy.

Edwards (1960) ran a study where subjects wore required to freely verbalize, make discerning guesses, and make a mujekple choled guess regarding a stimulus of subliminal exposure duration. 11 is results 
show differential sensitivity of the different methods with the most sensitive being the multiple choice task, the least sensitive the discerning guess'task, and free-verbalizing being lintemediate in sensitivity. Edwards suggests that "subliminal perception is an artifact of establishing a threshold by one method, then testing by another, nore sensitive method".

Howes (1954) has devised a statistical theory as an alternative explanation of the results found in studies on subliminal perception. His theory supports the symbolic-report hypothesls which statcs:

when an observer is given the task of discriminating among a set of stimuli, no measure of his success at that task is more sensitive than his symbolic (verbal) report. (Howes, 1954)

He concludes that

the statistical form of the symbolic-report hypothesis possesses far greater potentiality for the analytic description of perceptual phenomena than does the subception hy-.. pothesis: (Howes, 1954)

In a review of subliminal perception, Adams (1957) concludes that

the only type of behavior without awareness which can be easily reproduced on the basis of published reports is the classical type, in which the subject knows what he 18 supposed to be discriminating but does not know that he is discriminating because of the absence of the usual sensory experiences to which he is accustomed under the given lype of stimulation.

IV. OPPOSING VIEWS OF SUBLIMINAI PERCEPTION

Among the proponents of subliminal perception there are two rictions which are in opposition to each other. The Elrat consists of studies which have found subliminal perception to consist of a simple perception of structural differences in the subliminal stimuli. Struc- 
tural characteristiçs refer to such aspects as word length and the actual contour of the letters. For example, the letters $C$ and $O$ are very similar structurally, whereas $A$ and $J$ are structurally very dissimilar.

On the other hand, there are those who support the notion that responses to subliminal stimuli are of a semantic nature. Responses of a semantic nature include any judgment that is affected by the content of a subliminal stimulus, associative verbal responses to the stimulus, and larger GSRs for emotional as compared with neutral subliminai stimuli. This type of response engages some type of mental proccss.

\section{Structural Subliminal Effects}

Fuhrer and Eriksen (1960) investigated the hypothesis that the meaning of verbal stimuli may be responded to without prlor recognition of the stimulus. The subjects matched associations given to stimuli that had been exposed at illumination levels too weak for correct identification. Systematic employment of controls showed this to be a result of structural cues, such as word or phrase length, rather than "unconscious perception of stimuli meaning". Signiflcant results were obtained only at brightness levels which allowed the subject to detect the presence of the stimulus.

Banreti-Fuchs (1967) tested a similar hypothesis in a study where subjects were asked to "name the first word that comes to your mind" after words of positive and negative emotional quality were flashed at subliminal light intensities. The results falled to show that the subjects were responding differentially to the meaning and cmotional quality of the subliminally presented words. A second experiment was 
run as a pseudo-ESP study and subjects were required to guess the number that was supposedly on the back of some cards. Two series were run, one of which had the number five projected at subliminal Iight intensity simultaneously with the cue for guessing. Results showed that the subjects didn't respond to stimuli of which they were unaware. The results also showed no significant difference in reaction timcs to positive vs. negative stimulus words.

A study by Murch (1965) provided evidence in favor of the structural nature of subliminal perception. Subjects were given addition problems in a tachistoscope and simultaneously displayed a correct or incorrect answer at subliminal exposure durations. A significant tendency was found for subjects to repeat various subliminally projected digits in their answers without the answers directly affecting their computational processes.

Murch (1968) compared four methods of measuring the cffectivencss of visual subliminal stimulation. Each subject was presented with a total of ten relatively neutral faclal drawings with the word HAPPY (actually, FROH) or SAD (actually, BOSE) presented at Individually determined subliminal exposure durations. Afterwards, each subject was measured as to the effects of the subliminal stimulation by one of four methods. In the discrimination method, the subject was given a card upon which the words HAPPY and SAD were printed in a manncr corresponding exactly to the subliminal stimulus words. The discrimination with figural variation method required the subject to choose between the two words HAPPY and SAD printed differently from the subliminal stimulus words. With the description method the subject was informed that he/ she should describe each face as HAPPY or SAD, In the semantic dif- 
ferential method the subject described the face using a semantic differential containing seven pairs of opposites. The control group, which received no subliminal stimulation, was asked to describe the face using the discrimination method of pointing to the word best describing it. The results indicate that responses to subliminal stimuli are of a figural nature, and not of a cognitive nature. The discrimination method was the only one which differed significantly from the others. This method, as opposed to the others, does not require the assumption of a cognitive perceptual process. The figural elements of the subliminal stimuli may serve as cues for the correct response. Murch concludes with the possible hypothesis that this is the only method with which effects of subliminal stimuli can be found.

In accordance with the results of the above studies, Eriksen (1962) states that "the work of microgenetic schools suggests that the developmental stages in perception are geared around the physlcal rather than the psychological or meaning dimensions".

\section{Subliminal Effects of a Semantic Nature}

A variety of studies claim to support the hypothesis that subjects react to the content of a subliminal stimulus prior to specilic recognition of it. In a classic study, Smith, Spence, and KIcin (1959) tested the hypothesis that words exposed below the thrcshold of recogution and followed immediatèly by a clearly perceptible rigure would influence impressions of the latter. Subfects were exposed to a neutral face which was paired with either the word HAPPY or ANGRY flashed at subliminal exposure duration. They were then asked to describe the facc. It was found that the subliminal stimuli significantly incluenced the 
subjects' semantically related judgments of the facc, whth more pleasant déscriptions in the HAPPY-face pairings and more unpleasant descriptions in the ANGRY-face pairings. A preliminary study by Back and Klein (1957) and replications by Fox (1960) and Somekh and Wldding (1973) ylelded similar results.

Other studies have shown that subliminal stimuli have an cffect on the judgments subjects make of supraliminal stimul1. Klein, Spence, Holt, and Gourevitch (1958) used a masking effect whereby phenomenal representation of a first, briefly exposed, stimulus is totally prevented by an immediately succeeding second stimulus. Subjects wcre shown a drawing of a person ambiguous as to sex, inmediately precoded by either realistic or symbolic male or female genitals so that the person was the only stimulus reported by the subject. They were asked to draw and describe the figure. Results showed that the genital stimuli produced consistent results on both the dxawings and a checklist, whereas the effect of the symbolic genitalia was pronounced only on the drawings. However, both the meaning and form of the stinull secm to be crucial determinants and the investigators admit that the results could be due to the formal rather than connotative aspects of the stimuli. Eagle (1959) studied the effects of aggressive subliminal stimulf upon conscious cognition utilizing the masking procedure. A neutral plcture of a man ( $B$ stimulus) was immediately preceded by elther an aggresstue (a man stabbing another man) or nonaggressive (a man handing a birthday cake to another man) stimulus (A stimulus) of exposure durations ranging from subliminal to $200 \%$ of the measured threshold. Subjects were required to fill out a trait 1ist, draw a picture, and freely describe the $B$ stimulus. It was found that the A stimulus differentially af - 
fected responses to the $B$ stimulus as measured by the trait list ratings and drawings. When preceded by the aggressive A atimulus, the B figure was seen as more aggressive and generally more negative. The conclusion of this study is that stimuli which are not directly experienced can, nevertheless, register and influence conscious cognitive behavlor.

Byrne (1959) flashed the word "beef" at subliminal exposure duration every seven seconds during a movie to a group of subjects. From a questionaire filled out subsequently it was found that the subliminal food stimulus significantly increased subjective hunger ratings in the experimental group, as compared with the control group, which received no stimulation. However, it did not increase verbal refercnces to the stimulus word, or increase subjective hunger. A high drive state, measured by tïme since last meal, wasn't found to be a necessary condition for influence by subliminal stimulation.

Stimuli flashed at subliminal exposure durations was found to effect writing behavior in a study by Zuckerman (1960). TAT cards, readily visible to the subjects, were temporarlly overlapped by a brief stimulus of either a blank card (condition 1), the words WRITE MORE (condition 2), or the words DON'T WRITE (condition 3). Control subjects were exposed to the TAT cards without the subliminal stimulation. While the control subjects increased their writing rate from condition 1 to condition 3 , it was found that one of the two subliminal suggestions (DON'T WRITE) significantly influenced the productivity of the subjects in describing the pictures. When the imperativos were presented at a supraliminal level, they had no consistent effect upon the subjects' story length. 
Spence and Holland (1962) studied the effects of a subliminal stimulus on recall. Subjects were presented with a 11st of words to recall, half of which were associates to the word CliEksE and half weren't. Before the words were read, one group was exposed to the word CIAEESE at subliminal illumination and exposure duration, one group was exposed to the word at above threshold levels, and the control group received no stimulation. Both the control and supraliminal groups showed no preferential recall of CHEESE associated words, but the subliminal group showed a significantly greater recall. The conclusion of this study is that a wordr makes contact with more of its associates when it's reg1stered out of awareness than when it's close to awareness or fully in awareness. However, Worthington and Dixon (1964) found that only long standing associations to particular stimulus arrays may be affected by stimulation below the awareness threshold. Dixon (1956) and Spence and Bressler (1962) have found that subjects responded to the meaning of subliminal stimuli and there was a positive relationship between the emotionality of the stimulus word and the subjects' response latency. A negative relationship between stimulus related words and rosponse latency was found by Spence (1961).

In a study by Eriksen, Azuma, and Hicks (1959) subjects were shown pleasant and unpleasant words (as rated by the subjects) at subliminal illumination and exposure duration. They were asked to judge whether the word was: pleasant or unpleasant and to guess what the word was. In the absence of specific recognition or identification of the stimuli, the subjects.' affective judgments were more often correct than could be attributed to chance. Werner (1956), in his studies of microgenesis of the percept, found that most subjects gave some evidence of experiencing 
spheres of meaning prior to the specific articulation and signification of the verbal material. Lazarus (1956) also supports the theory that affective discrimination occurs temporarlly prior to specific 1dentiflcation during the process of perception.

Perceptual defence is a phenomenon whereby recognition thresholds depend upon the emotional connotation of that which is recognized. It's related to the theory of subliminal stimulation presented in the above studies and will be dealt with in a very limited sense in this paper Insofar as it provides evidence for the theory stated above. A well known study by McGinnies (1949) is typical of many in the area of perceptual defense. Eleven neutral words and seven emotionally toned words were presented to subjects at subliminal exposure durations. GSR was measured for each word and the subjects were instructed to report what they saw on each exposure. Not only did subjects display significantly higher thresholds of recognition for the emotional vs. the neutral words, but they reacted with GSRs of significantly greater magnitude during subliminal presentation of the emotional words. Similar results were found by Dixon (1958 a and b).

Worthington (1961) ran a study similar to the one by Lazarus and McCleary (1951) where three of six words were assoclated with shock on one third of the conditioning trials. During the test series the subjects were presented with words previously conditioned to shock, words semantically related to the conditioned material, and neutral words at subliminal and supraliminal illumination and exposure durations. The subjects reported what they saw and had their GSK moasured after each exposure. It was found that the GSRs generalized to scmantically re- 
lated stimuli, even when they were presented below the recognition threshold.

\section{RELATIONSHIP BETWEEN STIMULUS INTENSTTY \& TYIE OF RISPONSE}

Correlations have been found between the basis for gucsuing behavior when the stimulus is subliminal and when $1 t^{\prime}$ s supraliminal. Fuhrer and Eriksen (1960) and Wiener and Schijler (1960) have found a positive relationship between the degree of awarcness of a visual stimulus and the emitting of a structurally simflar response. Worthington and Dixon (1964), Dixon (1971), and Somckh and W1lding (1973) have found that responses tend to be meaning-relatcd with subliminal stimuli and structure-related with supraliminal stimuli. ko:ules from the Spence and Holland (1962) study showed that morc assoclalcs were recalled at the subliminal level and more structurally rataci words 1 were recalled at near-liminal levels with partial cucs. Similarly, Zuckerman (1960) found that subliminal stimuli affecicd writing behavior while supraliminal stimuli did not and Eagle (1959) statcd that subliminal effects (judgments of meaning) are more marked when the stlmuli are well below the threshold than. when they are fust below it.

Opposite effects were found by Fox.(1960) where the subliminal. words HAPPY and ANGRY presented immediately preceding a neutral face produced greater effects in the supraliminal vs. the subliminal condition.

Still another finding was reported by Smlth, spence, and kif in (1959) where stimuli at the upper end of the sublinfmal stimulus range provided no greater judgment effect than those at lhe lower cnd.

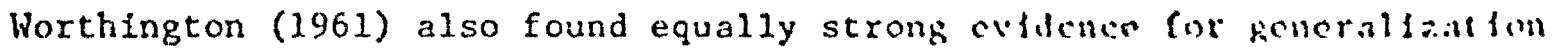


to semantically related words under subliminal and supraliminal conditions. 
CHAPTER II

\section{RESEARCH PROJECT}

This study was run to determine whether subliminal perception, if and when it occurs, involves a discrimination of structural characteristics or a discrimination of the semantic quality of words prior to specific identification. It was also an attempt to find the relationship between stimulus awareness (subliminal vs, partial cue vs. supraliminal) -and the type-of response (structural vs.-meaning-related).... Thresholds were measured individually using an increasing method of limits with a tachistoscope so that subliminal, partial cue, and supraliminal levels of exposure duration were established for each $\underline{s}$.

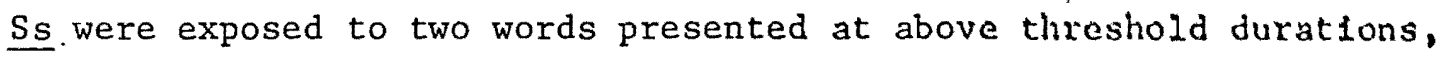
immediately preceded by either a subliminal, partial cue, or supralininal stimulus word, or a blank card. Condition I was run to find if subliminal perception exists as a function of elther structure or cognition. After the subliminal, partial cue, supraliminal, or blank flash stimulus the $\underline{S}$ was given two word choices. Word A was the same word (same structure and same meaning) and word B was a noutral word. A neutral word was not structurally similar to nor an associate of the stimulus. If the $\underline{S}$ chose A significantly more often than $B$, he/she was responding on the basis of either structure or meaning. The other conditions were run to find which of these he/she was responding to. Condition II was run to test specifically for responsea made on the basis 
of structure. Choice $A$ in this condition was a word having the same structure as the stimulus word, but not an associate. Cholce B was a neutral word. If the $\underline{S}$ responded on the basis of structure, he/she should choose A significantly more often than B. Condition III tested for responses made on the basis of meaning. The $\mathbf{S}$ chose between word A, which was an associate to the stimulus but different in structure, and word $B$, which was a neutral word. If the $\underline{S}$ responded on the basis of meaning, he/she should choose A significantly more often than $B$. The purpose of Condition IV was to find which is a stronger basis for making responses at the various stimulus durations: structure or meaning. Choice A had the same structure as the stimulus word, but was not an associate. Choice $B$ was an associate to the stimulus word, but different in structure. If the $\underline{s}$ responded on the basis of structure, he/she should choose A significantly more often than $B$. If he/she responded on the basis of meaning, he/she should choose B significantly more often than A. The E recorded the level of stimulation of the stimulus word (subliminal, partial cue, or supraliminal), the S's choice, and the condition of each trial. The order of presentation of $A$ and $B$, of each condition, and of the variations in each condition were determined randomly for each trial to control for response bias.

\section{METHOD}

\section{Apparatus}

Stimulus words and blank stimuli were presented with a three channel tachistoscope (scientific prototype, Model Gli) which was operated manually. Each channel was, illuminated by two $320 \mathrm{v}$. gas diecharge 
lamps. All field̦s were adjusted to equivalent brightness by means of a photometer placed at the viewing aperture. The brightness values were fixed at 20 FTC. The illumination in the room was also placed at a fixed value for each $\underline{S}$. During the threshold measurement a fixation point was placed in the blank field, the stimulus word was in field two, and a blank card was placed in field one. The expcrimont itself showed the stimulus word in field two, a blank card in the blank fleld, and the choice words in field one.

The $\underline{S}$ was equipped with a key with which he/she could activate the presentation of the stimulus.

Stimulus words were printed in black capital letters in the center of five by seven -inch white cards with a-3/4-inch gothic stencil. The twelve word associates have an associative frequency ranging from 515 to 840 from a sample of 1,008 Ss (Russell and Jenkins, 1954).

The amount of structural similarity between words was deccrmined by placing corresponding letters of the two words on top of each other and determining their lines in common. Calculations were mado for each pair of letters as to whether they had $0,25 \%, 50 \%, 75 \%$, or $100 \%$ of their lines in common. The percent of common lines for each letter pair was added together and divided by the number of lotters in each word. The words which are similar in structure have a ratio of: $\left.\frac{\text { amount of similarity in corresponding letters }}{\text { number of letters in the word }}\right\rangle .75$ The neutral words have a ratio of: amount of 'similarity in corresponding letters number of letters in the word .25 Word length is such a strong structural cue that an attampt was made to make each pair of words have an equal number of letters. Where this 
was not possible. (eight of the twenty-four different presentations) the ratio of lines in common was computed for each possible combluation of letter pairings and an average was taken.

\section{Procedure}

Experiment I. The experiment lasted approximately one hour for each $\underline{S}$,. during the first half of which the $\underline{S}$ ' threshold levels were measured. The $S$ sat in front of the viewing aperture and placed his/her head so that the hood was in place around the eyes. The $\underline{S}$ was then told by the $\underline{E}$ :

I'm going to flash words at different exposuro durations and I'd like you to tell me if you see 1) a blank flash (change in lighting), 2) part of a word, or 3) a word. When you can identify a word, please let me know what it 1 s. You will have to press the key on your right in order to activate the stimulus.

The $\underline{E}$ said "okay" every time the $\underline{S}$ was to press the key. Wwenty of the stimulus words were presented at $.5 \mathrm{msec}$, and incroased by the $E$ in increments of $.5 \mathrm{msec}$. until the $\underline{\mathrm{S}}$ correctly identifled the word. The $\underline{S}$ then took a short rest while the $\underline{E}$ computed the varlous thresholds. The subliminal threshold was found by using the longest exposure duration at which the $\underline{S}$ saw nothing or a blank flash on all twenty words. The supraliminal threshold was the exposure duration at whlch the $\underline{S}$ saw all twenty words plus $.5 \mathrm{msec}$. The partial cue threshold was cstablished by taking the value halfway inbetween the subliminal and supraliminal threshold.

Each $\underline{S}$ was run through thirty-two trials: elght in ench of the four conditions, during the second part of the experiment. A signal detection forced choice technique was used to optimize renponding. liefore beginning, the $\underline{E}$ gave the $\underline{S}$ the following instructions: 
I am going to give you a choice of two words. Sometimes there will be a word flashed before each cholce and sometimes there won't.' After I show you the two words please choose one of them and tell me what it 18 . Then tell me it there was 1) a blank flash, 2) something unintelligible, or 3 ) a word flashed beforc the cholce.

The choice words followed the stimulus. word by $150 \mathrm{msec}$. Each condition had two trials with each of the following:

1) Subliminal word presented before each of the choiccs

2) Partial cues presented before each of the cholces

3) Supraliminal word presented before each of the cholces

4) No word presented before each of the choices

Experiment II. The study was run again with $a$ change in the method of threshold measurement because there was an extremely low correlation between what the Ss reported during the threshold measurement and what they reported during the actual study in Experiment I. The method of threshold measurement was changed so that the conditions of measurement were the same as the conditions in the second part of the study. The stimulus word was flashed at $.5 \mathrm{msec}$, and increased by $.5 \mathrm{mscc}$, followed $150 \mathrm{msec}$. 1ater by the choice words. The $\underline{S}$ was told to report what he/she saw before-the choice words were seen. The socond part of the experiment was run the same as in Experiment I.

\section{Subjects}

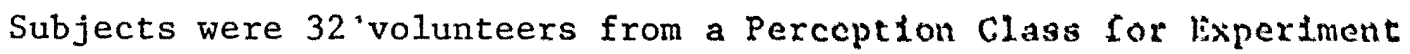
I. They included 18 males and 14 females. AlI Ss had normal vision or vision that was corrected to normal. The Ss for Experiment II were 25 volunteers-from-a-Perception-Class; two Psychology graduate students, and five students from other Psychology classes. Theso fncluded 16 malcs 
and 16 females.

\section{Statisticàl Aràlysis}

The data were broken down for all Ss combined into categorles indicating the type of response made when the exposure duration (from the threshold measurement) was defined as supraliminal and the $\underline{S}$ reported as supraliminal during the experiment; when the exposure duration was supraliminal and the $\underline{S}$ reported a partial cue; when the exposure duration was supraliminal and the $\underline{S}$ reported a blank flash, etc. The normal curve test (Edwards, 1963) was performed for each condition in each of the twelve categories (as defined above) to find if there was a significant difference between choices for the same word vs, a neutral word (Condition I), for a structurally slmilar word vs. a neutral word (Condition II), for an associate vs. a neutral word (Condition III), and for a structurally similar word vs. an associate (Condition IV).

\section{RESULTS}

The Ss verbal reports of the stimulus duration at which he/she saw a blank flash, part of a word, or a word were compared during the threshold measurement and the actual study (see Table I). In Experiment I the Ss reported a blank flash $71 \%$ of the time when the stimulus was supraliminal, $84 \%$ of the time when it was partial cue, $98 \%$ of the time when it was indeed subliminal, and $96 \%$ of the time when no word was flashed. No further analysis was performed on this data since the Ss didn't see anything in a significant number of the trials.

In Experiment II it was found that when the stimulus was supra- 
liminal, the Ss. saw a word $90 \%$ of the time, part of a word $3 \%$ of the time, and a blank flash $7 \%$ of the time. When the stimulus was flashed at an exposure duration previously defined by the $\underline{S s}$ as a partial cue they saw a word $83 \%$ of the time, part of a word $6 \%$ of the time, and a blank flash $11 \%$ of the time. At a stimulus duration previously defined as subliminal a word was reported on $40 \%$ of the trials, part of a word was reported on $27 \%$ of the trials, and a blank flash was reported on $33 \%$ of the trials. During the control condition when no word was flashed the Ss reported seeing a word on $.4 \%$ of the trials, part of a word on $5.1 \%$ of the trials, and a blank flash on $94.5 \%$ of the trials (see Table I).

Significant differences were found in the Ss cloice of words when they could identify the stimulus word during the study (see Table II). It was found that, using the normal curve test (Edwards, 1963), at a stimulus duration defined in the threshold measurements as supraliminal,

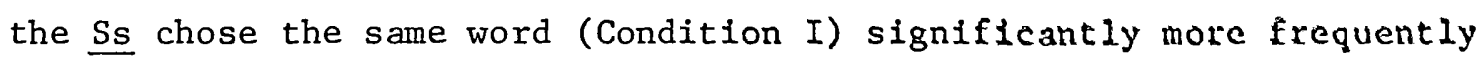
than a neutral word $(p=.008)$; a structurally simllar word (Condition II) significantly more frequently than a neutral word $(p=.0059)$; and an associate (Condition III) significantly more often than a neutral word $(p=.0021)$. There was no significant difference between choices of $a$ structurally similar word or an associate in the fourth condition when the stimulus word was defined and reported to be supraliminal.

There were also significant differences found when the stinulus word was defined as a partial cue during the threshold measurement and when the $\underline{s}$ could identify the word during the study. The same word (Condition I) was chosen significantly more often than a neutral word $(p=.0001)$; an associate (Condition II) was chosen algniflcantly more 
often than a neutral word $(\mathrm{p}=.0052)$; and an associate was chosen $\mathrm{s} 1 \mathrm{~g}-$ nificantly more often than a structurally simliar word $(p=.0197)$. There was no significant difference in cholces between a structurally similar word and a neutral word in Condition II when the stimulus word was defined as a partial cue but identifled by the Ss.

When the stimulus word was defined in the threshold measurements as subliminal but identified by the Ss during the study, they chose the same word (Condition I) significantly more often than the neutral word $(p=.0139)$. There were no other significant differenccs in clotces in the other three conditions when the stimulus word was defined as subliminal but identified in the study.

The significant differences in choices noted above all occurred when the $\underline{S}$ could identify the word during the study. There was one significant difference in choices when the $\underline{S}$ reported seeing nothing. When the stimulus word was defined in the threshold measurement as supraliminal, but the $\underline{S}$ seport a blank flash during the study, they chose the same word (Condition I) signiflcantly more often than the neutra1 word $(\mathrm{p}=.0071)$

There were no significant differences in cholces in the control procedure when no stimulus word was flashed. 


\section{CHAPTER III}

\section{DISCUSSION}

All but one of the significant differences in cholces vere found when the subjects could identify the word during the study. Subliminal perception, as defined in this paper, is a process whercby a subject reports no awareness of a visual stimulus and yet his/her verbal behavior, subjectively experienced as "guesses", is influenced by the stimulation. - Since the subjects could.identify. the stimulus word, their. choice behavior cannot be attributed to subliminal offects.

The subjects did choose the same word significantly more often than a neutral word (Condition I) when the stimulus was flashed at exposure durations previously defined as above the awareness threshold but reported in the study as a blank flash. This result is a classical one in terms of its evidence for subliminal perception. The subjects reported no awareness of the stimulus and yet they were able to discriminate the subliminal stimulus word from a neutral word.

The subliminal effect found in this study can be scen as support for the structural theory of subliminal perception. The only condition in which the subjects significantly chose one word over the other with no reported awareness was when one of the cholce words was Identical to the stimulus word. They didn't choose a structurally similar, but not identical, word significantly more often than a neutral word. It is suggested that subliminal perception is restricted to the discrimination 
of identical structural characteristics of the stimuli.

This may be: related to the phenomenon whereby subjects are able to recognize a stimulus they have seen before they are able to recall it. Luh (1922) exposed subjects to ninety series, each consisting of twelve nonsense syllables. He asked them to anticipate (recall) the syllables in half of the series and to select the original syllables from a second list of syllables (recognition) in the other half. It was found that the subjects recognized the words before they were able to recall them. 'It seems that recognition was more sensitive in picking up learning. In the present study the subjects chose the same word they had seen before significantly more often than a neutral word, but they didn't choose word associates or words structurally simflar, but not identical, to the stimulus word. Thus, they could recognize a word they had seen before, but they didn't make any assoclations or generalize to structurally similar, but not identical words. Just as recognition was found to be more-sensitive than recall in Luh's (1922) study, so was the recognition of an identical word in the present study more sensitive than the choosing of an associate or a structurally sim1lar, but not identical, word.

It is possible that the subjects received partial cues from the stimulus, although they reported nothing, which were sufficlont to allow them to make this discrimination. According to the partial cue explanation, the subject perceives fragments of the stimulus which enable him/her to guess correctly. The fragments which the subject perceives are structural characteristics of the stimulus. Thus, the possibility of the perception of partial cues is conslstent with the results as explained by the structural theory in that the cues that the 
subjects possibly picked up were structural ones. However, if the more sensitive measure of recognition of an identical word is due to partial cues, the subjects should have chosen a sigufleantly grater number of the structurally similar words than neutral words, but not as many as the identical words due to the lower probability of getting an adequate partial cue.' There weren't enough responses in that catcgory (subjects reported a blank flash, but according to threshold measurement, should have seen the word) for structurally similar words, however to find if that is, indeed, the case.

The present study showed what a great variance there is in the assigning of values to thresholds. In Experiment I the subjects reported seeing a blank flash $71 \%$ of the time when the stimulus was defined as supraliminal in previous measurements, and $84 \%$ of the time when it was previously defined as partial cue. It is suggested that this was due to a backward masking effect. During threshold mosurement the stimulus word alone was flashed and the subject was asked to report what he/she saw. The values obtained were used in the actual study where the stimulus word was followed $150 \mathrm{msec}$. later by two cholce words. It's possible that the choice words masked the stimulus word so that the threshold values (subliminal, partial cue, and supraliminal) obtalned during threshold measurement weren't appropriate for the atudy.

In Experiment II the conditions of presentation were the same in the threshold measurement and the actual study. In both cascs the stimulus word was followed $150 \mathrm{msec}$. later by the two cholce words and the subjects were asked to report what they saw before the choice words appeared. Even under these conditions there wasn't a perfect correla- 
tion between the threshold values (subliminal, partial cue, and supraliminal) during threshold measurement and the actual study. At an exposure duration defined as 'supraliminal during threshold measurement, the subjects still reported only part of a word $3 \%$ of the time and a blank flash $7 \%$ of the time during the study. At an exposure duration previously defined as partial cue, the subjects reported a word $83 \%$ of the time and a blank flash $11 \%$ of the time. When the exposure duration was previously. defined as subliminal, the subjects reported a word on $40 \%$ of the trials and a blank. flash on $33 \%$ of the trials. These results warrant some question of the traditional view of throshold. An alternative view of the sensory threshold is that of signal detection theory. According to this theory, there is no sensory cut-off point, rather externally applied signals merely increase the probability of raising the excitation level to a point at which the subject makes the decision to report the presence of a signal. As Dixon (1971) explains, signal detection theory emphasizes the fact that the behavior of responding to an external stimulus is really a two stage process. The first is sensing, the second that of deciding upon the sort of response that is warranted by what has been sensed. Traditional threshold determinations fail to distinguish between what a person senses and what he/she says he/she senses. Dixon (1971) goes on to state that, according to this theory, the subject's criterion for making a particular judgment is.itself variable, and dependent upon a number of factors unrelated to stimulus energy, for example, the prior probability of a signal and the pay-offs which accrue from what the receiver does in relation to the stimulus.

What a subject reports seeing is also a function of the number and 
kinds of response choices in the experimental situation. For example; suppose a subject is given à choice of saying "yes" or "no" as to whether or not he/she detects a visual stimulus. Viewing this in terms of signal detection theory, we can see that a subject may recelve some visual cues, but not enough to report "yes", so he/she says "no". The present study attempted to optimize the accuracy of responding by giving the subjects three choice responses (blank flash, part of a word, a word) and by forcing them to respond in one of these ways. One way to further optimize responding would be to give the subjects more verbal response choices, such as to have the subject report exactly what he/she saw.

Thus, subliminal stimulation is often followed by behavior which has been termed "behavior without awareness" and many studics have supported this. 'However, if we could make the subjects' verbal reports a more accurate description of what the subject actually perceived, we may find that subliminal perception is actually an artifact of the subjects' verbal reports rather than the sensing stage or responding to an external stimulus.

\section{CONCLUSION}

The conclusion of the present study is that subliminal perception involves a subjects responding to the identical structural characteristics of a stimulus. It's possible that the subjects respond only to stimuli from which they receive partial cues, since this study found classic evidence for subliminal perception only when the subject should have seen the stimulus, according to previous measurements, but did not report it. However, this is difficult to determine because responding to stimuli involves not only sensing, but also a decialon, based on 
individual and varying criteria, of what to report. 
REFERENCES

Adams,..J...K.. Laboratory studies of behavior without awareness. Psychological: Bulletin, 1957, 54, 383-405.

Bach, S. and Klein,..G...S. Effect of prolonged subliminal exposure of words. 'American Psychologist, 1957, 12, 397-398.

Baker, I..E. The influence of subliminal stimuli upon verbal behavior. Journal of Experimental Psychology, 1937, 20, 84-100.

Bartlett, F. C. 'Remembering. Cambridge University Press, 1932.

Bernstein, I. H. and Eriksen, C. W. Effects of subliminal prompting on paired-associate learning. Journal of Experimental Research in Personality, 1965, 1, 33-38.

Banreti-Fuchs, K. M. Perception without awareness. Acta. Psychologica, $1967,26,148-160$.

Boardman, W. K. Utilization of word structure in prerecognition responses. Journal of Personality, 1957, 25, 672-685.

Boardman, W. K. and Goldstone, S. Effects of subliminal anchors upon judgments of size. Perceptual and Motor Sk111s, 1962, 14, 475-482.

Bressler, J. Illusion in the case of subliminal visual stimulation. Journal of General Psychology, 1931, 5, 244-250.

Bricker, P. D. and Chapanis, A. Do incorrectly percelved tachistoscope stimuli convey some information? Psychological Revlew, 1953,60, 181-188.

Byme,..D. ...The effects of. a subliminal food stimulus on verbal responses. Journal of Applied Psychology, 1959, 43, 249-252.

Calvin, A. D. and Dollenmayer, K. S. Subliminal perception: Some negative findings.' Journal of Applied Psychnlogy, 1959, 43, 187188.

Champion, J. M. and Turner, W...W... An experimental Investigation of subliminal perception.' Journal of Applied Psychology, 1959, 43, 382-384.

Dixon,......F. ..Symbolic..associations following subliminal etimulation. International Journal of Psychoanalysis, 1956, 37 (23), 159-170. 
Dixon,.N. F. The effect.of..subliminal stimulation upon autonomic and verbal behavior. "Jourial of Abriormal and Soctal PBychology, 1958 (a), 57 (1), 29,-36.

Dixon, N. F. Apparent changes in the visual threshold as a function of subliminal..stimulation... A preliminary report. Quarterly Journal of Experimental Psychology, 1958 (b) , 10, 211-219.

Dixon, N. F. 'Subliminal perception: The nature of a controversy. London: McGraw-Hi11, 1971.

Dunlap, K....The effect of imperceptible shadows on judgment of distance. Psychological Review, 1900, 7, 435-453.

Eagle, M. The effects of subliminal stimuli of aggressive content upon conscious cognition. 'Journal of Personal1ty, 1959, 27, 578-600.

Edwards, A. C. Subliminal tachistoscopic perception as a function of threshold measurement. 'Journal of Psyehology, 1960, 50, 139-144.

Edwards, A. L. Design in psychological research. Holt, Rinehart, and Winston, New York, 1963.

Eriksen, C. W. An experimental analysis of subception. American Journal of Psychology, 1956 (a), 69, 625-634.

Eriksen, C. W. Subception: fact or artifact? Psychological Review, 1956 (b), 63, 74-80.

Eriksen, C. W. Unconscious processes. In Jones, M. R. (Ed) Nebraska Symposium on Motivation, Lincoln: Universfty of Nebraska Press, 1958.

Eriksen, C. W. Discrimination and learning without awarencss: a methodological survey and evaluation. Psychological Review, 1960, 67, 279-300.

Eriksen, C. W. Figments, fantasies, and follies: a search for the subconscious mind. In C. W. Eriksen (Ed.) Behavior and awareness. Durham, N. C.: Duke University Press, 1962.

Eriksen, C. W., Azuma, H., and Hicks, R. Verbal discrimination of pleasant and unpleasant stimuli. prior to specific Identification. Journal of Abriormal and Social Psychology, 1959, 59, 214-129.

Farne, M. Effects..of..so-called..subliminal. stimuli upon visual perception.' Psychological Research Bulletin, 1963, 3 (2).

Fox, M. Differential effects of subliminal stimuli and supraliminal stimulation. Unipublished doctoral dissertation, Now York University, $1960 . \ldots$ 
Fuhrer, M. J. and Eriksen, C. W. The unconsclous perception of the meaning of verbal stimuli. 'Journal of Abnormal and Soc1al Psychology, $1960,61,432-439$.

Gardner, R. W. and Lohrenz, L. J. Association and recall. Perceptual and Motor Skills, 1962, 15 (1), 29-30.

Goldberg, F. H. and Fiss, H. Partial cues and the phenomenon of "discrimination without awareness". Perceptual and Notor Sk111s; 1959, $9,243-251$.

Goldstein, M. E. Subliminal perception with optical IIlusions. Jourual of General Psychology, 1960, 62, 89-101.

Guthrie, G. and Wiener, M. Subliminal perception or the perception of partial cues with pictorial stimuli. Journal of Personality and Social Psychology, 1966, 3, 619-628.

Howes, D. H. A statistical theory of the phenomenon of subception. Psychological Review, 1954, 61, 98-110.

Kempler, B. and.Wiener, M. Personality and perception in the recognition threshold paradigm. Psychological Review, 1963, 70, 349-356.

Kempler, B. and Wiener, M. Personality-perception: Characteristic response to available part-cues. Journal of Personality, 1964, 32 (1), 57-74.

Kennett, J. R. Influence of subliminal stimuli on comparative judgments of length. Perceptual and Motor Ski1ls, 1962, 14, 338-389.

Kleespies, P. and Wiener, M. The "orienting reflex" as an input indicator in "subliminal" perception. Perceptual and Motor Sk111s, 1972,35 (1), 103-110.

Klein, G. S., Spence, D. P., Holt, R. R., and Gourevitch, S. Cognition without awareness: Subliminal influences upon consclous thought. Journal of Abnormal and Social Psychology, 1958, 57, 255-265.

Lazarus, R. S. Subception: Fact or artifact? A reply to Er1ksen. Psychological Review, 1956, 63, 343-347.

Lazarus, R. S. and McCleary, R. A. Autonomic discrimination without awareness: A study of subception. Psychological Review, 1951, 58, $113-122$.

Luh, C. W. The conditions of retention. Psychological Mondgraphs, $1922,142$.

McGinnies, E. Emotionality and perceptual defense. Paychological Review, $1949,56,244-251$. 
Miller;.J...G. Discrimination without awareness. 'Amerlcan Journal of Psychology, $1939, .52, .562-578$.

Murch, G. M. Suggestion for clarification.of terminology in experiments on subliminal stimulation. Perceptual and Motor Sk1118, 1964, 19 442 .

Murch, G. M. A simple laboratory demonstration of subception. British Journal of Psychology, 1965, 56, 467-470.

Murch, G. M. Temporal gradients of response to subliminal stimuli. Psychological Record, 1967, 483-492.

Murch, G. M. A comparison of several methods of measuring the effects of subliminal stimuli. Psychology, 1968, 5 (2), 20-26.

Murdock, B. B. Perceptual defense and threshold measurements. Journal of Personality, 1954, 22, 565-571.

Neisser, U. Cognitive psychology. New York: Appleton, Century, Crofts, 1967.

Russe11, W. A. and Jenkins, J. J. The complete Minnesota norms for responses to 100 words from the Kent-Rosanoff Word Assoclation Test. Tech. Rep. No. 11, Contract No. N8 ONR-66215 August, 1954.

Schiff, $W$. The effect of subliminal stimuli on guessing accuracy. American Journal of Psychology, 1961, 74, 54-60.

Sidis, B. The psychology of suggestion. New York: Appleton, 1898.

Smith, G. J. W. and Henriksson, M. The effect on an established percept of a perceptual process beyond awareness. Acta Psychologica, 1955. $2,346-355$.

Smith, G. J. W., Spence, D. P., and Klein, G. S. Subliminal effects of verbal stimuli. Journal of Abnormal and Social Psychology, 1959, 59 (2), 167-176.

Somekh, D. E. and Wilding, J. M. Perception without awareness in a dichotic viewing situation. British Journal of Psychology, 1973, 64 (3), 339-349.

Spence, D. P. The multiple effects of subliminal stimuli. Journal of Personality; 1961, 29, 40-53.

Spence, D. P. and Bressler, J. Subliminal activation of conceptual asm sociates: a study of "rational" preconsclous thinking. Journal of Personality, 1963, 30; 89-105.

Spence, $\rightarrow .-P:-$ and Holland, $B-$ The restrtcting effects of awareness: paradox and an explanation. Journal of Abnormal and Soc1:al Psycliology, 1962, 64, 163-174. 
Stroh, N. ,..Shaw, A. M., and Washburn, M. F. A study in guessing. American: Journal of Psychology, 1908, 243-245.

Titchner, E. B. and Pyle, W. H. The effect of Imperceptible shadows on the judgment of distance. Proc. Amer. PH11. Soc., 1907, 46, 94-109.

Trimble, R. and Eriksen, G. W. "Subliminal cues" In the Muller-type illusion. 'Percept: Psychophys., 1966, 1, 401-404.

Voor, J. H. Subliminal perception and subception. Journal of psychology, $1956,41,437-458$.

Washburn, M. F. and Manro, H. M. . The effect of imperceptible lines on the judgment of distance. 'American Journal of Psychology, 1908, 19,242 .

Werner, H. Microgenesis and aphasia. Journal of Abnormal and Social Psychology, 1956, 52, 347-353.

Wienér, M. and Kleespies, P. Some comments and data on the partial cue controversy and other matters relevant to investigations of subliminal phenomena: a rejoinder. Perceptual and Motor Sk111s, 1968, $27,847-861$.

Wiener, M. and Schiller, P. H. Subliminal percoption or perception of partial cues. Journal of Abnormal and Social psychology, 1960, 61, 124-137.

Williams, A. C., Jr. Perception of subliminal visual stimuli. Journal of Psychology, 1938, 6, 187-199.

Worthington, A. G. Semantic generalization and the nechanism of subception. Australian Journal of Psychology, 1961, 13 (2), 206-214.

Worthington, A. G. Effect of subliminal structural cues on reproductions of a simple line drawing. Perceptual and Motor Sk113s, 1964, $19,823-826$.

Worthington, A. G, and Dixon, N. F. Changes in gucssing habits as a function of subliminal stimulation. Acta Psycholosica, 1964, 22, $338-347$.

Zuckerman, M. The effects of..subliminal and supraliminal suggestion on verbal productivity. Journal of Abnormal and Social Psychology, 1960, 60 (3), 404-411. 
TABLE I

STIMULUS DURATION AS DEFINED IN

THRESHOLD MEASUREMENT AND

IN THE EXPERIMENT

\begin{tabular}{|l|c|c|c|}
\hline \multicolumn{3}{|c|}{ Experiment I } \\
\hline \multicolumn{3}{|c|}{ Subjects' Reports During the Study } \\
\hline & Word & Part of a Word & Blank Elash \\
\hline $\begin{array}{l}\text { Threshold } \\
\text { Measurement }\end{array}$ & & & \\
\hline $\begin{array}{l}\text { Supraliminal } \\
\sum=256\end{array}$ & $54(21 \%)$ & $21(8 \%)$ & $181(71 \%)$ \\
\hline $\begin{array}{l}\text { Partial Cue } \\
\sum=256\end{array}$ & $26(10 \%)$ & $14(5 \%)$ & $216(84 \%)$ \\
\hline $\begin{array}{l}\text { Subliminal } \\
\sum=256\end{array}$ & 0 & $5(2 \%)$ & $250(98 \%)$ \\
\hline $\begin{array}{l}\text { Contro1 } \\
\Sigma=256\end{array}$ & 0 & $10(4 \%)$ & $246(96 \%)$ \\
\hline
\end{tabular}

Experiment II

Subjects' Reports During the Study

\begin{tabular}{|l|r|r|r|}
\hline & Word & Part of a Word & Blank Flash \\
\hline $\begin{array}{l}\text { Threshold } \\
\text { Measurement }\end{array}$ & & & \\
\hline $\begin{array}{l}\text { Supraliminal } \\
\sum=256\end{array}$ & $230(90 \%)$ & $9(3 \%)$ & $17(7 \%)$ \\
\hline $\begin{array}{l}\text { Partial Cue } \\
\sum=256\end{array}$ & $213(83 \%)$ & $16(6 \%)$ & $27(11 \%)$ \\
\hline $\begin{array}{l}\text { Subliminal } \\
\sum=256\end{array}$ & $103(40 \%)$ & $69(27 \%)$ & $84(33 \%)$ \\
\hline Control & $1(.4 \%)$ & $13(5.1 \%)$ & $242(94.5 \%)$ \\
\hline
\end{tabular}


TABLE II

SIGNIFICANT DIFFERENCES IN

CHOICE BEHAVIOR

\begin{tabular}{|c|c|c|c|c|}
\hline & \multicolumn{3}{|c|}{ Subjects' Reports During the Study } & \\
\hline & Word & Part of a Word & Blank Flash & \\
\hline $\begin{array}{l}\text { Threshold } \\
\text { Measurement }\end{array}$ & & & & Condition \\
\hline \multirow[t]{4}{*}{ Supraliminal } & $p=.008$ & & $p=.0071$ & $I$ \\
\hline & $\mathrm{p}=.0059$ & & & II \\
\hline & $\mathrm{p}=.0021$ & & & III \\
\hline & & & & IV \\
\hline \multirow[t]{4}{*}{ Partial Cue } & $p=.0001$ & & & $I$ \\
\hline & & 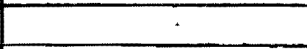 & & II \\
\hline & $p=.0052$ & & & III \\
\hline & $p=.0197$ & & & IV \\
\hline \multirow[t]{4}{*}{ Subliminal } & $p=.0139$ & & & $I$ \\
\hline & & & & II \\
\hline & & & & $\overline{\text { III }}$ \\
\hline & & & & IV \\
\hline \multirow[t]{4}{*}{ Contro1 } & & & & $I$ \\
\hline & & & & II \\
\hline & & & & III \\
\hline & & & & IV \\
\hline
\end{tabular}


TABLE III

STIMULUS WORDS AND CHOICE WORDS

\begin{tabular}{|c|c|c|c|c|c|c|c|c|}
\hline Stimulus Words & \multicolumn{8}{|c|}{ Choice Words } \\
\hline Condition I & \multicolumn{2}{|c|}{ Same Word } & \multicolumn{2}{|c|}{$\begin{array}{l}\% \text { of Structural } \\
\text { Similarity }\end{array}$} & \multicolumn{2}{|c|}{ Neutral Word } & \multicolumn{2}{|c|}{$\begin{array}{l}\text { \% of Structural } \\
\text { similarity }\end{array}$} \\
\hline \begin{tabular}{|l} 
ball \\
coal \\
grass \\
ocean \\
hope \\
pick \\
\end{tabular} & \multicolumn{2}{|l|}{$\begin{array}{l}\text { ball } \\
\text { coal } \\
\text { grass } \\
\text { ocean } \\
\text { hope } \\
\text { pick }\end{array}$} & \multicolumn{2}{|c|}{$\begin{array}{l}100 \% \\
100 \% \\
100 \% \\
100 \% \\
100 \% \\
100 \%\end{array}$} & \multicolumn{2}{|r|}{$\begin{array}{l}\text { Into } \\
\text { this } \\
\text { happy } \\
\text { still } \\
\text { seen } \\
\text { home }\end{array}$} & \multicolumn{2}{|r|}{$\begin{array}{c}19 \% \\
0 \\
0 \\
20 \% \\
19 \% \\
19 \% \\
\end{array}$} \\
\hline Condition II & \multicolumn{2}{|c|}{$\begin{array}{l}\text { Struc. } \\
\text { Similar } \\
\text { Word }\end{array}$} & \multicolumn{2}{|c|}{$\begin{array}{l}\% \text { of Structural } \\
\text { Similarity }\end{array}$} & \multicolumn{2}{|c|}{ Neutral Word } & $\begin{array}{ll}\% & 0 \\
5\end{array}$ & $\begin{array}{l}\text { E Structural } \\
\text { imilarity }\end{array}$ \\
\hline $\begin{array}{l}\text { add } \\
\text { card } \\
\text { name } \\
\text { said } \\
\text { life } \\
\text { tree } \\
\end{array}$ & \multicolumn{2}{|l|}{$\begin{array}{l}\text { and } \\
\text { hard } \\
\text { same } \\
\text { sail } \\
\text { lift } \\
\text { free }\end{array}$} & \multicolumn{2}{|c|}{$\begin{array}{l}75 \% \\
75 \% \\
75 \% \\
88 \% \\
87 \% \\
94 \% \\
\end{array}$} & \multicolumn{2}{|r|}{$\begin{array}{l}\text { bay } \\
\text { near } \\
\text { play } \\
\text { flow } \\
\text { road } \\
\text { also }\end{array}$} & & $\begin{array}{c}0 \\
13 \% \\
4 \% \\
0 \\
13 \% \\
4 \% \\
\end{array}$ \\
\hline Condition III & $\begin{array}{l}\text { Word } \\
\text { Ass. }\end{array}$ & $\begin{array}{l}\% \\
\text { Sim }\end{array}$ & $\begin{array}{l}\text { of Struc. } \\
\text { milarity }\end{array}$ & $\begin{array}{l}\text { Number } \\
\text { Ass./1, } \\
\text { subject }\end{array}$ & $\begin{array}{l}\text { of } \\
008 \\
\text { s }\end{array}$ & Neutral $\mathrm{W}$ & ord & $\begin{array}{l}\% \text { of Struc. } \\
\text { Similarity }\end{array}$ \\
\hline $\begin{array}{l}\text { black } \\
\text { boy } \\
\text { table } \\
\text { blossom } \\
\text { eagle } \\
\text { tobacco } \\
\end{array}$ & $\begin{array}{l}\text { white } \\
\text { gir } 1 \\
\text { chair } \\
\text { flowef } \\
\text { bird } \\
\text { smoke }\end{array}$ & & \begin{tabular}{l|}
$15 \%$ \\
$21 \%$ \\
$20 \%$ \\
$24 \%$ \\
$22 \%$ \\
$20 \%$ \\
\end{tabular} & $\begin{array}{r}751 \\
768 \\
840 \\
672 \\
550 \\
515 \\
\end{array}$ & & $\begin{array}{l}\text { often } \\
\text { over } \\
\text { story } \\
\text { letter } \\
\text { soap } \\
\text { sreen }\end{array}$ & & \begin{tabular}{r|}
$20 \%$ \\
$9 \%$ \\
$5 \%$ \\
$17 \%$ \\
$19 \%$ \\
$17 \%$ \\
\end{tabular} \\
\hline Condition IV & $\begin{array}{l}\text { Word } \\
\text { Ass. }\end{array}$ & $\begin{array}{l}\% \circ \\
\text { Sim }\end{array}$ & $\begin{array}{l}\text { of Struc. } \\
\text { milarity }\end{array}$ & $\begin{array}{l}\text { Number } \\
\text { Ass. } / 1 \text {. } \\
\text { subject }\end{array}$ & $\begin{array}{l}\text { of } \\
008 \\
\text { s }\end{array}$ & $\begin{array}{l}\text { Structura } \\
\text { Similar } \\
\text { Jard }\end{array}$ & $11 y$ & $\begin{array}{l}\text { Xof SERUC. } \\
\text { Similarity }\end{array}$ \\
\hline $\begin{array}{l}\text { dark } \\
\text { long } \\
\text { king } \\
\text { hard } \\
\text { high } \\
\text { slow }\end{array}$ & \begin{tabular}{|l|} 
light \\
short \\
queen \\
soft \\
low \\
fast \\
\end{tabular} & & $\begin{array}{l}22 \% \\
22 \% \\
19 \% \\
19 \% \\
24 \% \\
19 \% \\
\end{array}$ & $\begin{array}{l}829 \\
758 \\
751 \\
674 \\
675 \\
752 \\
\end{array}$ & & $\begin{array}{l}\text { bark } \\
\text { song } \\
\text { ring } \\
\text { lard } \\
\text { slgh } \\
\text { blow }\end{array}$ & & $\begin{array}{l}88 \% \\
75 \% \\
94 \% \\
81 \% \\
81 \% \\
88 \%\end{array}$ \\
\hline
\end{tabular}

